\title{
Explaining the Gender-Gap in Economic Activity: A Cross-Country Study
}

\author{
Yaseen Mamdouh Altarawneh ${ }^{1}$ \\ ${ }^{1}$ Business Economics Department, School of Business, The University of Jordan, Amman, Jordan \\ Correspondence: Yaseen Mamdouh Altarawneh, Business Economics Department, School of Business, The \\ University of Jordan, Amman, Jordan. Tel: 962-79-176-3199.
}

Received: June 17, 2020

Accepted: August 2, 2020

Online Published: September 3, 2020

doi:10.5430/rwe.v11n5p16

URL: https://doi.org/10.5430/rwe.v11n5p16

\begin{abstract}
This study aims at investigating the cross-country variation in gender-gap in economic activity. A balanced panel data for 72 countries with complete data for the period 2000-2016 were extracted from the World Bank indicators. The statistical diagnostic tests supported the use of the fixed effect model. The series was stationary at level and not co-integrated. Moreover, the null hypothesis of the appropriateness of random effect model was rejected. The estimated results assure the importance of demand side factors in dampen the gender gap in economic activity as expected such as GDP growth, gender gaps in employment, in being self-employed and unemployment, urbanization and trade openness. Surprisingly, the supply side factors such the cross-country variation in gender gap in education and fertility rates were no more important determinants in explaining the gender gap in economic activity. This study recommends governments to improve the demand-side factors that would encourage more female employment and reduce the gender gap in economic activity later.
\end{abstract}

Keywords: gender gap in economic activity, labor force participation, gender inequality

\section{Introduction}

Gender refers to the socially constructed characteristics of women and men, such as norms, roles and relationships of and between groups of women and men (WHO, 2011). Gender issues became today one of the important topics which scientific research aims to tackle as they have interdisciplinary relation with all economic, social, demographic and/ or developmental dimension in the society. The importance of such topic is growing, especially in developing countries, where a woman suffers in general from many problems such as unemployment, social exclusion, poverty, marginalization, etc.

Despite the substantial progress, the gender gap in economic activity rates still persists especially in many developing countries (WEF, 2017). Based on World Bank Indicators (WBI, 2019), this study adopts the ratio of female to male labor force participation rate in each country to explain the gender gap in economic activity. This indicator is calculated by dividing female labor force participation rate by male labor force participation rate and multiplying by 100. Based on World Bank data in last 20 years (World Bank indicators; 2019), There are huge cross country variation in gender-gap in economic activity. Recently in 2019, some countries have revealed high ratio (exceed 90\%) of female to male labor force participation rate which means low gender gap in economic activity such as Azerbaijan, Benin, Liberia, Norway, Nepal, Sweden, Burundi, Rwanda. While other countries have revealed huge gender gap in economic activity- very low ratio of female to male labor force participation rate (less than 30\%) such as Yemen republic, Syrian Arab Republic, Iraq, Algeria, Iran and India.

The importance of this study stems from two main facts: first: it is a comprehensive cross-country study that includes all countries with complete data (72 countries). Second: it is the first study that relates the cross-country variation in economic activity to cross-country differences in other economic, social and demographic variables at macro level.

Therefore, the main objective of this study is to explain the cross country variation in gender gap in economic activity through the variations in economic, social and demographic aggregate factors. Examples of these aggregate factors (which created by author) that represent the demand side factors are gender-gaps in being employer, in employment, being self-employed and the gender-gap in unemployment. The other group of factors which represent the supply side factors are the gender-gap in education, GDP growth, trade openness, urbanization, foreign direct investment, health expenditures and fertility rate. So, this study comes to elaborate the reasons behind the variation 
in economic activity among countries included, and through answering the following main question: Do the differences in gender cause variations in the economic activity in selected countries?

\section{Figures and Facts: A Cross-Country Analysis of Gender Gap in Economic Activity}

Table (1) shows facts about the evolution of gender gap in economic activity measured by the ratio of female to male labor force participation rate for selected countries around the world for the period 1990-2019(WBI, 2019). Those countries were selected based on data availability for all variables included in the econometric model during the period 2000-2016.

For the whole world, this ratio was stable around $66.6 \%$ over the period $1990-2019$ which reflect a gap of $33.4 \%$ between the female and male activity rates. This figure assures the existence of the problem of gender gap in economic activity

In details, some individual countries have achieved high ratio of female to male labor force participation rate which in turn decreasing the gender gap in economic activity such as Australia, Brazil and Germany, while other countries have witnessed an increase in gender gap such as China and India. For china, the gender gap increased from $13.7 \%$ in 1990 to $19.6 \%$ in 2019 and for India, the gap increased from $64.3 \%$ to $70.2 \%$ during the same period.

Table 1. Ratio of female to male labor force participation rate (\%)

\begin{tabular}{|c|c|c|c|c|c|c|c|}
\hline Selected country/ countries & 1990 & 1995 & 2000 & 2005 & 2010 & 2015 & 2019 \\
\hline \multicolumn{8}{|l|}{ individual countries: } \\
\hline Argentina & 56.8 & 64.1 & 67.0 & 65.4 & 64.4 & 65.2 & 67.2 \\
\hline Australia & 69.1 & 72.6 & 75.5 & 79.0 & 81.0 & 83.0 & 84.7 \\
\hline Bahrain & 33.1 & 36.1 & 40.1 & 45.2 & 50.1 & 50.3 & 51.0 \\
\hline Brazil & 50.4 & 58.1 & 63.8 & 70.4 & 69.9 & 70.8 & 72.6 \\
\hline Bulgaria & 88.3 & 85.9 & 79.2 & 79.3 & 80.1 & 80.9 & 80.4 \\
\hline China & 86.3 & 85.7 & 85.4 & 83.7 & 81.9 & 81.4 & 80.4 \\
\hline France & 70.5 & 75.6 & 77.3 & 80.1 & 82.2 & 83.6 & 84.1 \\
\hline Germany & 62.3 & 68.9 & 72.4 & 76.0 & 79.4 & 82.5 & 83.6 \\
\hline India & 35.7 & 36.4 & 36.6 & 38.6 & 32.0 & 29.7 & 29.8 \\
\hline Iran, Islamic Rep. & 12.2 & 13.8 & 18.9 & 26.1 & 22.8 & 21.5 & 23.3 \\
\hline Jordan & 15.5 & 17.7 & 18.4 & 18.0 & 22.7 & 21.8 & 22.2 \\
\hline Spain & 50.1 & 57.2 & 61.8 & 67.8 & 76.6 & 80.9 & 81.8 \\
\hline \multicolumn{8}{|l|}{ Group of countries: } \\
\hline World & 66.5 & 67.1 & 67.6 & 67.6 & 66.9 & 66.7 & 66.7 \\
\hline Latin America \& Caribbean & 51.5 & 56.5 & 59.9 & 64.2 & 65.6 & 66.5 & 67.7 \\
\hline East Asia \& Pacific & 80.2 & 80.1 & 80.0 & 78.6 & 78.0 & 77.8 & 77.3 \\
\hline European Union & 67.0 & 70.1 & 72.7 & 75.0 & 77.6 & 79.6 & 80.6 \\
\hline Middle East \& North Africa & 23.4 & 24.4 & 25.9 & 28.1 & 29.0 & 29.7 & 30.3 \\
\hline Central Europe and the Baltics & 78.3 & 77.2 & 77.8 & 75.9 & 75.3 & 75.5 & 75.7 \\
\hline Arab World & 25.7 & 26.5 & 26.9 & 27.4 & 28.9 & 30.1 & 30.4 \\
\hline South Asia & 35.3 & 35.8 & 36.3 & 38.2 & 33.8 & 32.9 & 33.7 \\
\hline Least developed countries & 71.3 & 71.5 & 72.4 & 73.0 & 73.6 & 74.6 & 75.9 \\
\hline Low income & 82.8 & 82.4 & 83.0 & 83.5 & 82.8 & 83.1 & 83.9 \\
\hline Lower middle income & 48.0 & 49.2 & 49.7 & 49.7 & 48.5 & 48.3 & 48.9 \\
\hline Upper middle income & 76.4 & 76.3 & 76.6 & 76.0 & 74.7 & 74.4 & 73.8 \\
\hline High income & 67.3 & 69.8 & 72.0 & 74.1 & 76.0 & 77.2 & 78.1 \\
\hline
\end{tabular}

\begin{tabular}{llllll}
\cline { 2 - 3 } Source: & World & Bank & Development & Indicators & (WBDI)
\end{tabular} http://databank.worldbank.org/data/source/world-development-indicators\#. 
Moreover, Table 1 shows the performance of selected groups of countries. Some groups have fallen back in the ratio of female to male participation ratio (increasing the gender gap) during the study period such as East Asia \& Pacific, Central Europe and the Baltics, South Asia and the Upper middle income countries. While other groups of countries have achieved higher ratio of female to male participation ratio (decreasing gender gap) during the same period such as Latin America \& Caribbean, European Union and Middle East \& North Africa.

Based on above facts, this study aims at analyzing the gender gap in economic activity by tying the cross-country variation in gender gap in economic activity with socioeconomic and demographic variations.

\section{Literature Review}

Some economists (Morrison, Raju, and Sinha, 2007) believe that gender inequality does not only negatively impact the quality of life and standard of living, but also affects economic dimensions. Unlike industrialized countries, females are considered as largely marginalized classes in the South, where they suffer unequal opportunities and little chances for social and economic empowerment compared to males due to many factors mainly related to the conditions of their primitive or developing communities. Despite that, such issue is still controversial in local communities, counties, and Worldwide (Galor\& Weil, 1993).

Up to the author's knowledge, there is a few studies that explain the cross-country variations in gender gap in economic activity at micro level (Kleven and Landais, 2017) and none at macro level. Most studies in this regard have investigated the determinants of female labor force participation rates (Sherverick, 2014; Jaumotte, 2003: Chen et al, 2014), the gender gap in wages (Khitarishvili, 2013; Schober and winter, 2011). Also, the economic benefits of gender-equality in labor market on economic performance. (Ahang, 2014; Ali, 2015; Klasen, 2018; Klasen and Lamanna, 2009; Cavalcanti and Tavares, 2016).

At micro level, the study of (Kleven and Landais, 2017) has documented a large convergence in economic activity rates and earnings of men and women over the path of development. This was driven mainly by demographic transition such as low fertility rate, convergence in educational attainment and the striking changes in the values or norms surrounding the role of women.

Olivetti and Petrongolo (2016) investigated the driving factors for gender convergence in industrialized countries in employment and pay both over time and across countries. Their study emphasizes the importance of evolution in the industry structure on gender convergence. Mainly, the growth in the service sector share can explain most of the overall variation in female participation. Also, (Gaddis and Klasen2014)) assures the importance of structural changes on women`s labor force participation rates.

The study of EIGE (2017) about the economic befits of gender equality in the European Union investigate the socio-economic impacts of increased gender equality and found that encouraging more women participation in the labor market and improving their attainment in education would have a significant positive effect on GDP per capita and employment of women.

The works of Klasen (2018) and Klasen and Manuel (2018) have reviewed most of the empirical literature at micro and macro level and report that gender gaps in employment and education reduce economic growth, with the effects being sizable and robust.

Vásconez Rodríguez (2018) investigates the relationship between the feminization of the labor market and economic growth in five Latin American countries and confirms that feminization of the labor force bears a positive relationship with economic growth.

Cuberes and Teignier (2011) argued that gender discrimination measured by restrictions on women access to managerial positions, participating in labor force and to access formal employment have showed a significant negative economic effects on resource allocation, aggregate productivity and on income per capita.

The study of Mukherjee and Mukhopadhyay (2013) analyzed the data for 61 developing countries of Asia, Africa and Latin America in 2010 and surprisingly documented that gender inequality in labor force participation has a positive impact on economic growth.

The study of Hakura. D et al (2016) found that both income and gender inequalities in Sub-Saharan Africa are negatively associated with per capita GDP growth mainly in lower income countries.

Ferrant (2011), reported that gender inequality would hinder economic and human development and provide an evidence how gender inequality might explain the economic development differences and the variations in per capita income between South Asia and East Asia \& Pacific. 
The recent study of Ferrant and Thim (2019) provide an evidence base on the gender gaps in unpaid care work and recognized the share of women unpaid work in GDP. As example it is around 33\% in China. Therefore, to enhance eth e women's economic empowerment, the women's unpaid care work must be recognized, reduced and redistributed.

For Arab Region, the study of Al-Shammari and Al Rakhis (2017) reported that no statistical evidence on empirical influence of gender inequality in education and labor market on the economic growth for the period 1990-2014. While in the context of the Jordanian economy, a study (Bataineh\&Athamneh, 2016) showed that the contribution of females to the national economy was higher than males during the period (1970-2012). Unlike other sectors, the study found the productivity of females was about three times for males in service sector, which in turn participates in two third of the national income of the country.

All in all, the analysis of the available cross-country studies in this field based mainly at micro level data and concerned in investigating the gender gap in wages and the determinants of female activity rates. In contrary, this study is the first study which based at macro level data in explaining the gender gap in economic activity on one side. On the other side, it is more comprehensive by including variety of economic, social and demographic variables for 72 countries.

\section{Data and Methodology}

To explain the cross country variation in gender gap in economic activity, this study use balanced panel data extracted from the World Bank indicators (WBI, 2019) for 72 countries with complete data over the period 2000-2016.

To investigate the possible relationship between the different socioeconomic and demographic factors and the gender gap in economic activity, the study will estimate the following model:(Arora, 2012), (Seguino, 2000), \& (Chaudhry, 2017)

$$
\mathrm{Y}=\mathrm{F}(\mathrm{Xi}) . \quad \mathrm{i}=1 \ldots 9
$$

Where:

Y: gender gap in economic activity measured by the ratio of female to male labor force participation rate.

Gender gap in economic activity as measured by the ratio of female to male labor force participation rate is a reciprocal index for the gender gap. When the value of this index equal one, there is no gender gap completely, and if the value of the index equal zero, there is completely gender gap in economic activity. Therefore, the explanatory variables with positive impact would decrease the gender gap and vice versa.

$\mathrm{X}_{1}$ : GDP growth rate.

$\mathrm{X}_{2}$ : Gender gap in education measured by the ratio of female to male school enrollment in tertiary level.

$\mathrm{X}_{3}$ : Gender gap in unemployment measured by ratio of female to male unemployment rate.

$\mathrm{X}_{4}$ : Gender gap in employment measured by the ratio of female to male employment ratio of total population $15+$.

$\mathrm{X}_{5}$ : Gender gap in being employer measured by the ratio of female to male employer ratio of total employment.

$\mathrm{X}_{6}$ : Gender gap in being self-employed measured by the ratio of female to male self-employed ratio of total employment.

$\mathrm{X}_{7}$ : fertility rate measured by total births per women.

$\mathrm{X}_{\mathbf{8}}$ : Urbanization ratio measured by the percentage of urban population to total population.

$\mathrm{X}_{\mathbf{9}}$ : openness degree measured by the ratio of trade to GDP.

To ensure the reliability of the model, the required statistical diagnostic tests for panel data were applied. The panel unit root test- Liven test -(Levin.A and C.-S. J. Chu., 2002) reveals that all series were stationary and not co-integrated. Moreover, based on the result of Hausman test (see Table 2), the null hypothesis is rejected that the preferred model is random effects (Hausman, 1978). Therefore, the study will use the panel fixed effect model to estimate the relationship among the explanatory variables and the gender gap in economic activity (Kiefer. M, 1980). 
Table 2. Correlated Random Effects - Hausman Test

\begin{tabular}{llll}
\hline $\begin{array}{l}\text { Correlated Random Effects - Hausman Test } \\
\text { Test cross-section random effects }\end{array}$ & & \\
\hline Test Summary Chi-Sq. Statistic & Chi-Sq. & d.f. & Prob \\
\hline Cross-section random & 127.339499 & 9 & 0.0000 \\
\hline
\end{tabular}

\section{Results and Explanation}

Based on the estimation results of the Cross-section fixed effects model as shown in table (2), the model is statistically significant and fit as the probability of F-statistics is less than $1 \%$ and $\mathrm{R}^{2}$ is high (99\%). Also all suggested explanatory variables were statistically significant except the gender gap in education. Even though, it shows positive impact on the dependent variable which means less gender gap in education is corresponding with less gender gap in economic activity as expected. This insignificant impact would be explained by the huge gap between the women education outcomes (Tertiary level as used in the study) and job opportunities. Recently, most of the unemployed and then discouraged women who are out of labor force are from educated women.

However, the GDP growth rate has showed positive and significant impact which in turn reduces the gender gap in economic activity. This would be explained by the fact that the created job opportunities accompanied by economic growth is in favor of women rather than men.

Regarding the impact of the gender gap in unemployment, it is very small but expected to have positive and significant impact on gender gap in economic activity. This result is due to the close interaction between the concepts of labor force and unemployment and because of the dominance of the Added Worker Effect which increase the female labor force participation rates during the recession periods (high unemployment periods).

The high positive and significant impact of the gender gap in employment on gender gap in economic activity is expected since the employment is part of total labor force. Therefore, the high employment ratio for females would reduce the gender gap in economic activity.

The other explanatory variable which reflects the women empowerment status such as the gender gap in being employer (decision maker) has shown negative and significant impact. This would be explained by the fact that women as employer is in favor of employing men rather than women. The high ratio of women being employers, the higher is the gender gap in economic activity. On the other side, the gender gap in being self-employed which reflects also the women empowerment and independence has shown positive and significant impact as expected. High ratio of female being self-employed would reduce the gender gap in economic activity.

The demographic factors such as fertility rate and urbanization have shown the expected and significant impact on the gender gap in economic activity. The high fertility rate would increase the gender gap because of the evidential fact about the negative relationship between the female labor force participation rate and fertility rate. High fertility rate is corresponding with high family responsibility and less market participation. Regarding the urbanization impact, it shows positive and significant impact on gender gap in economic activity which means that urban are offer more job opportunities than rural areas.

The last factor is the openness degree. It shows as expected positive and significant impact which assure the fact that trade openness is essential factor to enhances female employment and then reduce gender gap in economic activity. This result would indicate that export sector is female oriented in employment. 
Table 3. Estimation results: Cross-section fixed effects model

\begin{tabular}{|c|c|c|c|c|}
\hline \multicolumn{5}{|c|}{ Dependent variable: (Y) Gender Gap in Economic Activity } \\
\hline \multicolumn{5}{|c|}{ 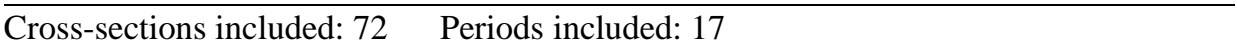 } \\
\hline \multicolumn{5}{|l|}{ Total panel (balanced) observations: 1224} \\
\hline Variable & Coefficient & Std. Error & t-Statistic & Prob. \\
\hline $\mathrm{C}$ & 10.41084 & 1.087443 & 9.573692 & 0.0000 \\
\hline $\mathrm{X}_{1}$ : : GDP growth rate & 0.041368 & 0.007009 & 5.902170 & 0.0000 \\
\hline $\mathrm{X}_{2}$ : Gender gap in education & $1.87 \mathrm{E}-08$ & 3.92E-08 & 0.476193 & 0.6340 \\
\hline $\mathrm{X}_{3}$ : Gender gap in unemployment & 0.001965 & 0.000388 & 5.059761 & 0.0000 \\
\hline $\mathrm{X}_{4}$; Gender gap in employment & 0.837868 & 0.007922 & 105.7676 & 0.0000 \\
\hline $\mathrm{X}_{5}$; Gender gap in being employer & -0.011910 & 0.003433 & -3.469430 & 0.0005 \\
\hline $\mathrm{X}_{6}$ : Gender gap in being self-employe & d 0.016171 & 0.003719 & 4.348235 & 0.0000 \\
\hline $\mathrm{X}_{7}$ : fertility rate & -0.872083 & 0.144484 & -6.035843 & 0.0000 \\
\hline $\mathrm{X}_{8}:$ : Urbanization ratio & 0.028028 & 0.012775 & 2.193904 & 0.0284 \\
\hline $\mathrm{X}_{9}$ : : openness degree & 0.003215 & 0.001677 & 1.916737 & 0.0555 \\
\hline R-squared & 0.998232 & Mean d & ependent var & 69.26551 \\
\hline Adjusted R-squared & 0.998108 & S.D. de & jendent var & 18.49527 \\
\hline S.E. of regression & 0.804529 & Akaike & info criterion & 2.466766 \\
\hline Sum squared resid & 739.8264 & Schwar & $\mathrm{z}$ criterion & 2.804920 \\
\hline Log likelihood & -1428.661 & Hannan & Quinn criter & 2.594022 \\
\hline F-statistic & 8065.020 & Durbin & Watson stat & 0.670480 \\
\hline$\overline{\operatorname{Prob}(F-\text {-statistic })}$ & 0.000000 & & & \\
\hline
\end{tabular}

\section{Conclusion and Policy Implications}

The study concludes that the supply side factors such as education and other family circumstances that would have enhance female labor force participation rates and reduce gender gap in economic activity are no more the main drivers for more female participation. The policy implication in this regard, governments is encouraged to reconsider the traditional education streams toward more technical and vocational skills which enhance female employability through expanding their job opportunities. Also, more polices and efforts are required to weaken the negative impact of high fertility on the gender gap in economic activity. Example is to enforce the provision of child care services at least in large companies with 20 workers or more.

Moreover, the study concludes that demand side factors are more effective in improving female labor force participation rates which reduce and dampen the gender gap in economic activity. Therefore, governments should pay more attention to the demand side factors such as increasing economic growth which in turn increase female employment and reduce the unemployment, structuring the labor market conditions to be more female friendly and absorb more female employment. In addition to decreasing imperfections and segmentation in labor market, this would be applied by allocating white collars jobs to women. Moreover, establish and update labor market regulations and policies to be in aligning with ILO regulations, organizing the labor market especially the unorganized sector where most women are working, also committed to all ILO and international conventions regarding women employment rights and anti-discrimination polices.

Finally, the study assures the importance of women empowerment measured by the gender gap in being employer and self-employed in increasing their employment and reducing the gender gap in economic activity. Governments should pave the way to transfer micro projects owned or managed by females from informal to formal sector so as to guarantee the sustainability of such projects. Moreover, governments are encouraged to devote for more women in leadership positions and provide micro finance for unemployed females to start their own small businesses. 


\section{References}

Ahang, M. (2014). The impact of Gender inequality on Economic Growth in Developed Countries. The Accounting, Economics and Financial Management Conference, 26-27 October 2014, Tehran, Iran.

Ali, M. (2015). Effect of Gender Inequality on Economic Growth. Case of Pakistan. Journal of Economics and Sustainable Development, 6(9).

Al-Shammari, N., \& Al Rakhis, M (2017). Impact of Gender Inequality on Economic Growth in the Arab Region. Research in Applied Economics, 9(2).

Arora, R. U. (2012). Gender inequality, economic development, and globalization: A state level analysis of India. The Journal of Developing Areas, 147-164.

Bataineh, B., \& Abdel-Baset Athamneh. (2016). The Productivity of Women in the Jordanian Labor Market: An Econometric Analysis (1970-2012). Jordan Journal of Economic Sciences, 3(2).

Cavalcanti, T. V., \& Tavares, J. (2016). The output costs of gender discrimination: A model-based macroeconomic estimate. Economic Journal, 126, 109-134.

Chaudhry, I. S. (2007). Gender inequality in education and economic growth: case study of Pakistan. Pakistan Horizon, 60(4), 81-91.

Chen, J., Xiaokuai, S., Ghulam, M., \& Zhongxiu, Z. (2014). Factors that Influence Female Labour Force Supply in China. Economic Modelling, 37, 485-491.

Cuberes, D., \& Teignier, M. (2011). Gender Inequality and Economic Growth, Gender Equality and Development. World Development Report 2012.

European Institute for Gender Equality (EIGE). (2017). Economic benefits of gender equality in the European Union (EU), Luxembourg: Publications Office of the European Union, 2017.

Ferrant, G. (2011). How Gender Inequalities Hinder Development: Cross-Country Evidence. CES Working Paper.

Ferrant, G., \& Thim, A. (2019). Measuring Women's Economic Empowerment: Time Use Data and Gender Inequality. OECD Development Policy Papers, No. 16.

Gaddis, I., \& Klasen, S. (2014). Economic Development, Structural Change and Women's Labour Force Participation: A Reexamination of the Feminization U Hypothesis. Journal of Population Economics, 27(3), 639-681.

Galor, O., \& Weil, D. N. (1993). The gender gap, fertility, and growth. National Bureau of Economic Research, No. w4550.

Hakura, D., Hussain, M., Newiak, M., Thakoor, V., \& Yang, F. (2016). Inequality, Gender Gaps and Economic Growth: Comparative Evidence for Sub-Saharan Africa. International Monetary Fund, IMF Working Paper, WP/16/111.

Hausman, J. A. (1978). Specification Tests in Econometrics. Econometrica, 46(6).

Jaumotte, F. (2003). Female Labour Force Participation: Past Trends and Main. Determinants in OECD Countries, OECD, Economics Department Working Papers, No. 376, OECD Publishing.

Khitarishvili, T. (2013). Evaluating the Gender Wage Gap in Georgia, 2004 - 2011. Levy Economics Institute of Bard College, Working Paper No. 768.

Kiefer, M. (1980). Estimation of Fixed Effect Models of Time Series of Cross-Sections with Arbitrary Intertemporal Covariance. Journal of Econometrics, 14, 195-202.

Klasen, S. (2018). The impact of gender inequality on economic performance in developing countries. University of Göttingen, Courant Research Centre - Poverty, Equity and Growth (CRC-PEG), Göttingen, Discussion Papers, No. 244.

Klasen, S., \& Lamanna, F. (2009). The impact of gender inequality in education and employment on economic growth: new evidence for a panel of countries. Feminist Economics, 15(3), 91-132.

Klasen, S., \& Santos Silva, M. (2018). Gender inequality as a barrier to economic growth: A review of the theoretical literature. University of Göttingen, Courant Research Centre - Poverty, Equity and Growth (CRC-PEG), Göttingen, Discussion Papers, No. 252. 
Kleven, H., \& Landais, C. (2017). Gender Inequality and Economic Development: Fertility, Education and Norms. Economica, 84(334), 180-209.

Levin, A., \& Chu, C.-S. J. (2002). Unit root tests in panel data: Asymptotic and finite-sample properties. Journal of Econometrics, 108, 1-24.

Morrison, A., Raju, D., \& Sinha, N. (2007). Gender equality, poverty and economic growth. The World Bank.

Mukherjee, P., \& Mukhopadhyay, I. (2013). Impact of gender inequality on economic growth: A study of developing countries. IOSR Journal of Humanities and Social Science (IOSR-JHSS), 13(2), 61-69.

Olivetti, C., \& Petrongolo, B. (2016). The evolution of the gender gap in industrialized countries, DP11034.

Schober, T., \& Winter-Ebmer, R. (2011). Gender wage inequality and economic growth: Is there really a puzzle? A comment. World Development, 39(8), 1476-1484.

Seguino, S. (2000). Gender inequality and economic growth: A cross-country analysis. World Development, 28(7), 1211-1230.

Sherverick. (2014). Female labour force participation in developing countries. IZA World of Labour 2014: 87, ILO.

The World Health Organization (WHO). (2011). Gender mainstreaming for health managers: a practical approach. Retrieved from http://www.who.int/gender-equity-rights/knowledge/glossary/en/

Vásconez Rodríguez, A. (2018). Economic growth and gender inequality: an analysis of panel data for five Latin American countries. CEPAL Review, 120, 79-106.

World Bank Development Indicators (WBDI) database. (2019). Retrieved from http://databank.worldbank.org/data/source/world-development-indicators\#

World Economic Forum. (2017). Accelerating Gender Parity in the Fourth Industrial Revolution. An Agenda for Leaders to Shape the Future of Education, Gender and Work. Retrieved from www.weforum.org

\section{Copyrights}

Copyright for this article is retained by the author(s), with first publication rights granted to the journal.

This is an open-access article distributed under the terms and conditions of the Creative Commons Attribution license (http://creativecommons.org/licenses/by/4.0/). 